\title{
Embolization of renal tumor bone metastasis: case report
}

\section{Embolização de metástase óssea de tumor renal: relato de caso}

\author{
Felipe Soares Ribeiro ${ }^{1}$ (D), Salim Abdon Haber Jeha² (D), José Victor Figueiredo dos Santos ${ }^{3}$ (D), \\ Ananda Vitória Suzuki Barros Damasceno ${ }^{4}$ (D), Tereza Maria Meireles Fernandes da Silva ${ }^{4}$ (D), \\ Fernando Brasil do Couto Filho' (D), Humberto Balbi Reale Neto ${ }^{4}$ (D)
}

\begin{abstract}
Primary or secondary bone tumors can manifest in different ways, from simple bone pain to possible pathological fractures. Hypervascularized tumors are of greatest concern, with increased incidence of complications. Preoperative embolization of the bone tumor is an effective measure for reducing blood loss during open surgery to excise the tumor. With appropriate experience, the risks of the procedure are minimal and final outcomes are highly satisfactory. The purpose of this paper is to describe the case of a 43-year-old male patient with a metastatic renal cell tumor in the left proximal femur (seen on lower limb computed tomography) who underwent selective preoperative embolization. The procedure resulted in a remarkable absence of bleeding and successful response to subsequent onco-orthopedic surgery.
\end{abstract}

Keywords: renal cell carcinoma; arterial embolization; bone metastasis.

\section{Resumo}

Os tumores ósseos, primários ou secundários, podem se manifestar de várias formas, desde dor óssea até fraturas patológicas. A preocupação maior repousa sobre tumores hipervascularizados, com maior incidência de complicações. A embolização pré-operatória do tumor ósseo é uma medida eficaz para reduzir a perda sanguínea durante a exérese tumoral em cirurgia aberta. Com uma experiência apropriada, os riscos do procedimento são mínimos, com resultados finais bastante satisfatórios. O presente artigo tem por finalidade descrever o caso de um paciente do sexo masculino, de 43 anos, com tumor metastático de células renais em fêmur proximal esquerdo (visualizado por angiotomografia de membro inferior), submetido à embolização arterial seletiva pré-operatória. O procedimento resultou em ausência de sangramento e ótima resposta à cirurgia onco-ortopédica realizada.

Palavras-chave: carcinoma de células renais; embolização arterial; metástase óssea.

How to cite: Ribeiro FS, Jeha SAH, Santos JVF, Damasceno AVSB, Silva TMMF, Couto Filho FB, Reale Neto HB. Embolization of renal tumor bone metastasis: case report. J Vasc Bras. 2021;20:e20210005. https://doi.org/10.1590/1677-5449.210005

\footnotetext{
${ }^{1}$ Hospital Porto Dias, Belém, PA, Brasil.

${ }^{2}$ Universidade Federal do Pará - UFPA, Belém, PA, Brasil.

${ }^{3}$ Faculdade Metropolitana da Amazônia - UNIFAMAZ, Belém, PA, Brasil.

${ }^{4}$ Universidade do Estado do Pará - UEPA, Belém, PA, Brasil.

Financial support: None.

Conflicts of interest: No conflicts of interest declared concerning the publication of this article.

Submitted: January 20, 2021. Accepted: April 05, 2021.
}

The study was carried out at Hospital Porto Dias, Belém, PA, Brazil. 


\section{INTRODUCTION}

Kidney cancer is the twelfth most common type of malignancy worldwide, with incidence in males twice the rate in females. ${ }^{1,2}$ Metastases are frequent in renal neoplasms and the bone is the second most common site, with an incidence of $30 \%{ }^{3}$

Locoregional treatments have emerged as an important element for symptom control, improving therapeutic results and offering quality of life to these patients. ${ }^{4}$

Arterial embolization is defined as a locoregional treatment to selectively devascularize hypervascularized tumors, slowing their growth without affecting adjacent organs. ${ }^{5}$ It also delivers a more positive prognosis, enabling pain reduction, reducing the risk of spontaneous bleeding, and decreasing the likelihood of bleeding during orthopedic oncologic surgery. ${ }^{6}$

This study aims to report the results of selective arterial embolization performed in a patient with a bone metastasis from renal carcinoma, attesting to the functionality and benefit of this procedure as an important element in satisfactory cancer treatment outcomes.

The protocol was approved by the institution Ethics Committee (Decision number 4.582.420).

\section{CASE REPORT}

The patient was a 43-year-old Brazilian man who works as a store salesperson and had a medical history of nephrectomy and surgical resection of a metastatic spine lesion about 12 months earlier. After these procedures, he was diagnosed with metastatic lesions in the retroperitoneum, bones, and lung. $\mathrm{He}$ was admitted to the emergency room of our service complaining of severe pain in his left thigh.

Upon initial physical examination, he was in regular condition, without fever, and hemodynamically stable. Computed tomography was performed, revealing a lytic lesion on the left proximal femur neck, MIRELS classification $11,{ }^{7}$ with a high risk of a pathological fracture (Figure 1). The diagnostic hypothesis was metastatic bone lesion of the proximal femur derived from a renal cell carcinoma.

The patient was referred to the vascular surgery team for evaluation and preoperative embolization was indicated. Subsequently, the oncologic orthopedics team performed an open resection of the proximal femur and replacement with prosthesis. For the embolization, the patient was placed in the horizontal supine position under spinal anesthesia. The right common femoral artery was punctured with a 5-French introducer sheath. A pigtail catheter and a 0.035 hydrophilic guidewire were used to cross the contralateral iliac territory and catheterize the left common femoral artery. Arteriography was performed from multiple incidences, showing a tumor blush at the proximal femur neck (Figure 2) with blood supply from deep femoral branches (lateral femoral circumflex artery and smaller branches). The deep femoral branches were
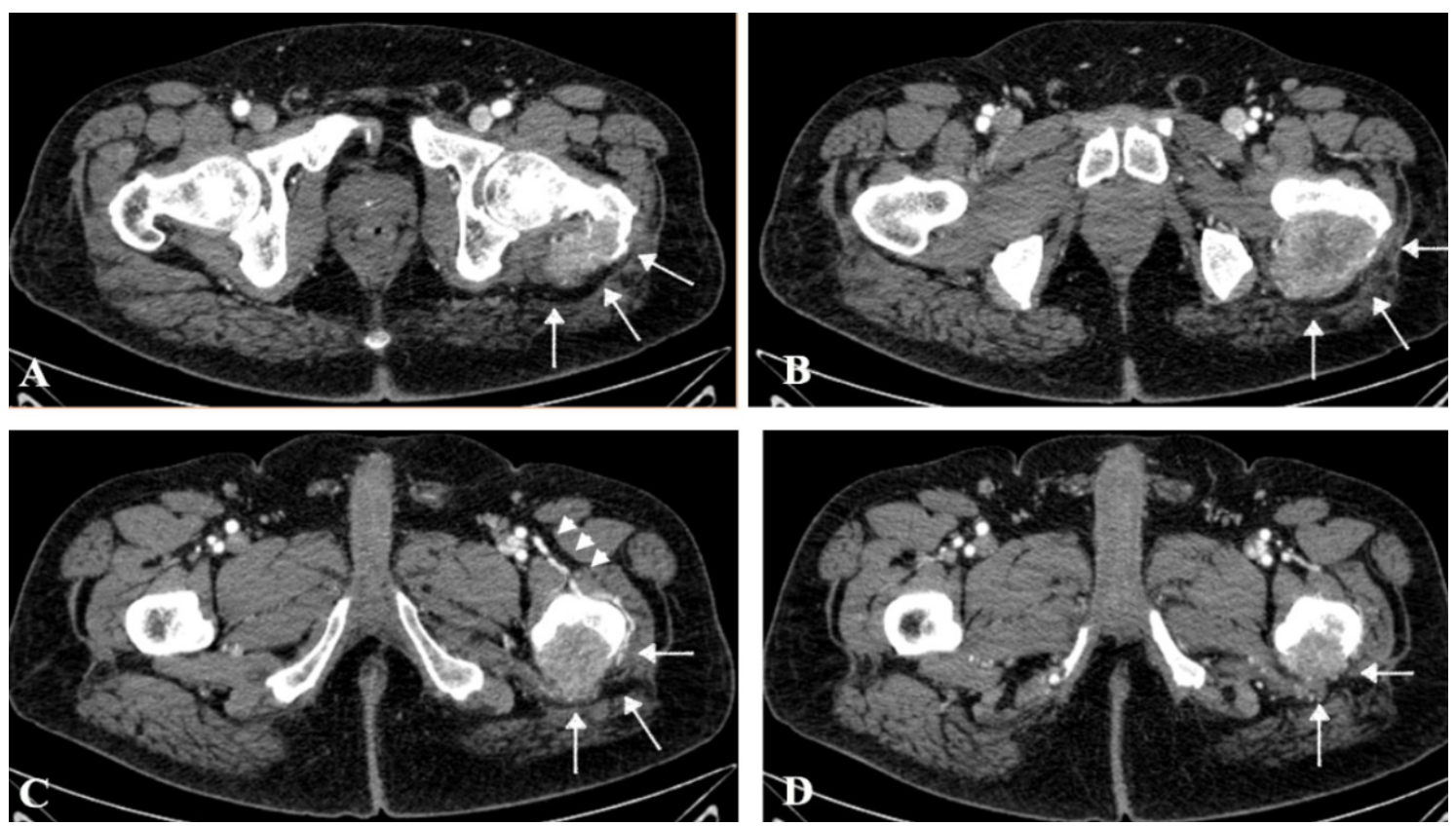

Figure 1. Angio-CT axial slice showing renal cell carcinoma metastasis at the femoral neck. (A) Tumor apex at the femoral neck (white arrows); (B) Proximal third of Bone Tumor (white arrows); (C) Distal third of Bone Tumor (white arrow) and arterial supply of the deep femoral artery (white arrowhead); (D) Bottom of the Bone Tumor. 

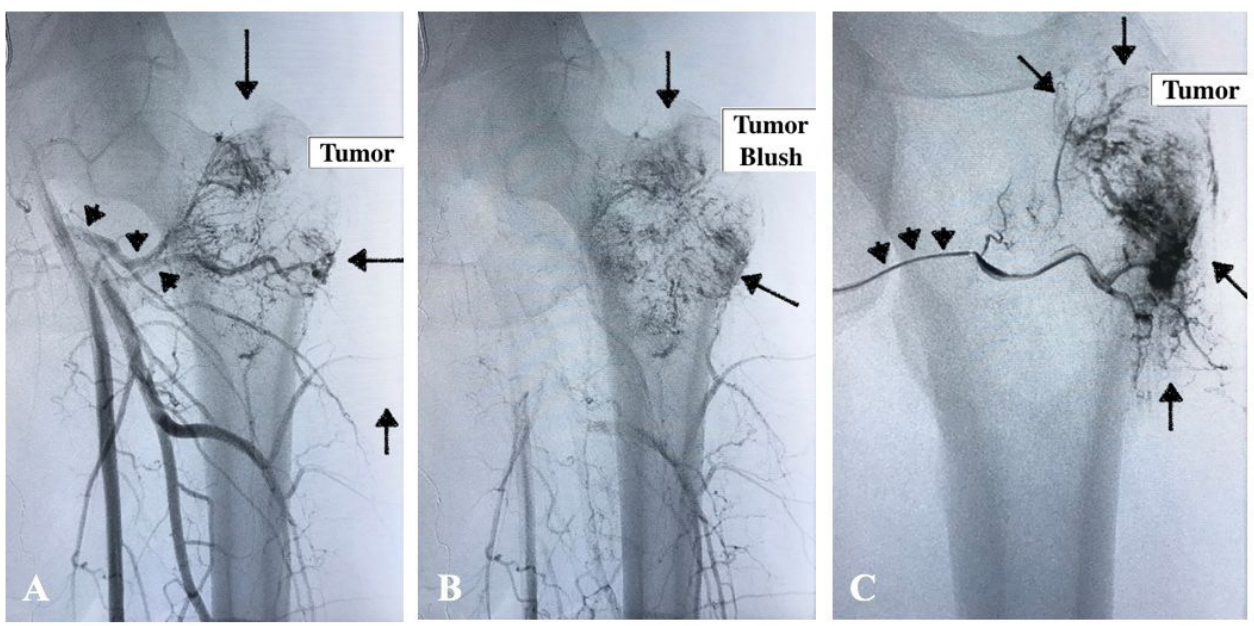

Figure 2. Left limb arteriography. A) Arterial supply to the tumor by deep femoral artery branches (black arrowheads) and initial tumor blush at the femoral neck (black arrows); B) Tumor blush at the left femoral neck (black arrows); C) Superselective arterial catheterization (black arrowheads) showing tumor blush (black arrows)
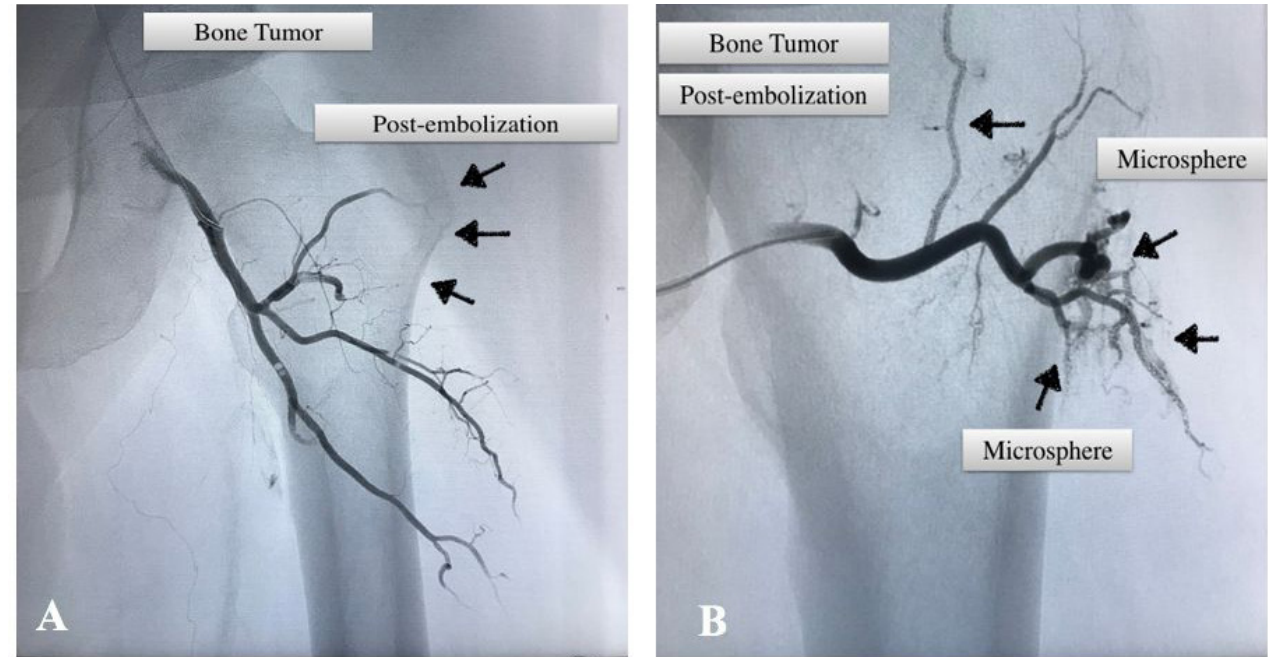

Figure 3. Post-embolization left limb arteriography. A) Absence of tumor blush at femur neck (black arrows); B) Microspheres inside arterial branches of the tumor (black arrows).

catheterized with a Vert catheter and the smaller tumoral branches with a Progreat ${ }^{\circledR}$ microcatheter (Terumo Corporation, Shibuya, Tokyo, Japan). Subsequently, embolization was performed with Embosphere ${ }^{\circledR}$ 300-500 $\mu \mathrm{m}$ microspheres (Merit Medical, Utah, USA), obtaining complete devascularization on the final arteriography (absence of tumor blush) (Figure 3).

After 48 hours, the patient underwent an orthopedic procedure under spinal anesthesia. A $20 \mathrm{~cm}$ lateral incision was made in the proximal left thigh, followed by dissection until complete tumor visualization was achieved. An $11 \mathrm{~cm}$ section of the proximal left femur was removed along with the tumor mass (Figure 4). There were no intraoperative complications, bleeding, or need
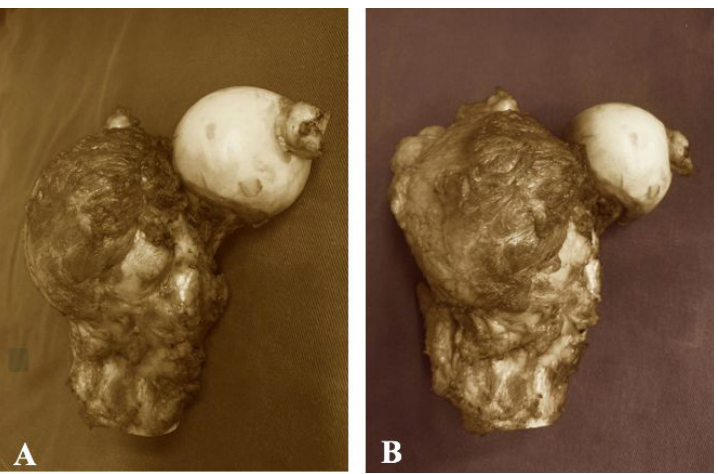

Figure 4. A and B) Bone tumor - resected renal cell carcinoma metastasis. 
for blood transfusion. The surgical specimen was sent to the pathology department and was later confirmed to be a bone metastasis from a renal cell carcinoma.

The patient maintained follow-up with the oncology and orthopedics teams. He underwent a chemotherapy regimen for renal cell carcinoma. Positive results were obtained. There were significant reductions in pain score and need for analgesics and improvement in quality of life.

\section{DISCUSSION}

Renal cell carcinomas have a high incidence of bone metastasis. They are one of the metastatic diseases with most embolization reports in the literature. ${ }^{8}$ These bone tumors are hypervascularized, especially when they originate from renal cell carcinomas, and they are a cause for considerable concern with regard to bleeding during open surgical procedures. ${ }^{9,10}$

In the mid-1970s, superselective and selective embolization was used to reduce perioperative bleeding in a case series of bone tumor embolizations. ${ }^{11}$ Since then, selective arterial embolization has emerged as an isolated procedure or as part of a broader therapeutic set, bringing benefits such as pain relief (decompression of the periosteum and reduction of neurological symptoms) and improving these patients' quality of life. ${ }^{12,13}$ Therefore, considering the excellent pain control results, some authors believe it to be a first-line palliative therapy. ${ }^{14,15}$

According to Pazionis et al., not performing preoperative embolization may result in massive bleeding with an increased risk of patient morbidity. Furthermore, in patients at high cardiological risk, severe bleeding can also increase mortality and embolization may be essential for this reason. ${ }^{16,17}$

Since its advent, several techniques and materials have been tested to improve the embolization procedure. The case series by Feldman et al. used Gelfoam ${ }^{\circledR}$ for embolizations, but this substance has only a temporary occlusive effect, with recanalization of the vessel occurring in a few weeks. Other embolic agents have been developed. Currently, polyvinyl alcohol particles, N-butyl-cyanoacrylate, and trisacryl microspheres are available. ${ }^{4}$ In this study, the microsphere embolization technique was used because it is applicable to vessels of smaller caliber, in addition to the more uniform and homogeneous size.

A study compared a group of patients comprising 27 kidney cancer patients and 12 thyroid cancer patients who underwent selective bone tumor embolization prior to surgery to a group of 41 patients who did not. This comparative study demonstrated reduced blood transfusion requirements ( 2.15 versus $3.56 \mathrm{U} ; \mathrm{p}=0.020)$, diminished blood loss $(0.90$ versus $1.77 \mathrm{~L} ; \mathrm{p}=0.002)$, and shorter operation time (3.13 versus 3.91 hours; $\mathrm{p}<0.001)$ for the group treated with embolization, demonstrating the functionality reported by the literature and the significance of this procedure. ${ }^{16}$

In patients with indications for tumor resection, one relevant factor in post-embolization surgical success is the period between the two procedures, considering that after a few days there is a progressive increase in local neovascularization and, therefore, the bleeding risk returns. ${ }^{17}$ Current literature recommends that the open surgery be carried out at most three days after the embolization. ${ }^{17}$ After that, neoangiogenesis occurs and there is a new cumulative risk of bleeding. The patient in this case report was successfully subjected to open left femur resection with prosthetic replacement 48 hours post-embolization.

Although rare, embolization involves some risks inherent to the procedure, with emphasis on arterial dissection; accidental embolization of adjacent vessels; muscle necrosis; transient paresthesia in the lower limbs (most common); and contrast nephropathy. However, the incidence of serious complications, such as acute ischemia, is lower than $1 \%$. The procedure is therefore considered to be quite safe and has a low morbidity rate when performed by an experienced team..$^{5,16}$

Currently, only one case series demonstrating the experience with the bone tumor embolization technique is available in the literature. It is therefore necessary to conduct prospective studies to evaluate not only short-term results, but also the late postoperative period and the impact on the survival of these patients over an extended follow-up.

Selective and superselective preoperative embolization of renal cell carcinoma metastasis plays an important role among oncological treatment options. It offers patients greater autonomy, better pain control, independence, and improved quality of life.

\section{CONCLUSION}

Arterial embolization with microspheres is a safe and effective preoperative treatment for patients with bone metastasis from renal cell carcinomas, with significant clinical benefits especially regarding pain relief, low complications rates, and a significant reduction in the risk of intraoperative hemorrhage during the oncological orthopedic procedure (tumor resection and replacement with prosthesis).

\section{REFERENCES}

1. Ferlay J, Steliarova-Foucher E, Lortet-Tieulent J, et al. Cancer incidence and mortality patterns in Europe: estimates for 40 countries in 2012. Eur J Cancer. 2013;49(6):1374-403. http://dx.doi. org/10.1016/j.ejca.2012.12.027. PMid:23485231. 
2. Tahbaz R, Schmid M, Merseburger AS. Prevention of kidney cancer incidence and recurrence: lifestyle, medication and nutrition. Curr Opin Urol. 2018;28(1):62-79. http://dx.doi.org/10.1097/ MOU.0000000000000454. PMid:29059103.

3. Bianchi $M$, Sun $M$, Jeldres $C$, et al. Distribution of metastatic sites in renal cell carcinoma: a population-based analysis. Ann Oncol. 2012;23(4):973-80. http://dx.doi.org/10.1093/annonc/mdr362. PMid:21890909.

4. Gatto L, Facchini G, Saponara M, et al. Successful selective arterial embolization for bone metastases in renal cell carcinoma integrated with systemic therapies: A case report. Radiol Case Rep. 2017;12(4):775-9. http://dx.doi.org/10.1016/j.radcr.2017.07.008. PMid:29484069.

5. Lau V, Sun M, Chu F. Embolization of hypervascular bone tumours: A pictorial essay with literature review. J oMed Imaging. Radiat Oncol. 2013;57(2):191-7. PMid:23551777.

6. Leenknegt B, Pesapane F, Huang D. Pre-Operative trans-arterial embolization of a Hypervascular bone metastasis. J Belg Soc Radiol. 2019;103(1):9. http://dx.doi.org/10.5334/jbsr.1694. PMid:30671567.

7. Mirels H. Metastatic diseases in long bones, a proposed scoring system for diagnosis impending pathologic fractures. Clin Orthop Relat Res. 1989;(249):256-64. PMid:2684463.

8. Rossi G, Mavrogenis AF, Casadei R, et al. Embolization of bone metastases from renal cancer. Radiol Med (Torino). 2013;118(2):291302. http://dx.doi.org/10.1007/s11547-012-0802-4. PMid:22430676.

9. Owen RJ. Embolization of Musculoskeletal Bone Tumors. Semin Intervent Radiol. 2010;27(02):111-23. http://dx.doi. org/10.1055/s-0030-1253510. PMid:21629401.

10. Forauer AR, Kent E, Cwikiel WH, Esper P, Redman B. Selective palliative transcatheter embolization of bony metastases from renal cell carcinoma. Acta Oncol. 2007;46(7):1012-8. http://dx.doi. org/10.1080/02841860701280725. PMid:17851849.

11. Feldman F, Casarella WJ, Dick HM, Hollander BA. Selective intra-arterial embolization of bone tumors: $\mathrm{A}$ useful adjunct in the management of selected lesions. Am J Roentgenol Radium Ther Nucl Med. 1975;123(1):130-9. http://dx.doi.org/10.2214/ ajr.123.1.130. PMid:1119647.

12. Van Tol KM, Hew JM, Jager PL, Vermey A, Dullaart RP, Links TP. Embolization in combination with radioiodine therapy for bone metastases from differentiated thyroid carcinoma. Clin Endocrinol (Oxf). 2000;52(5):653-9. http://dx.doi.org/10.1046/j.13652265.2000.00998.x. PMid:10792347.

13. Facchini G, Di Tullio P, Battaglia $M$, et al. Palliative embolization for metastases of the spine. Eur J Orthop Surg Traumatol. 2016;26(3):247-52. http://dx.doi.org/10.1007/s00590-015-1726-y. PMid:26667933.

14. Yu X, Xu M, Xu S, Fu Z. Long-term outcome of giant cell tumor of bone involving sacroiliac joint treated with selective arterial embolization and curettage: a case report and literature review. World J Surg Oncol. 2013;11(1):72. http://dx.doi.org/10.1186/14777819-11-72. PMid:23497322.
15. Lackman RD, Khoury LD, Esmail A, Donthineni-Rao R. The treatment of sacral giant-cell tumours by serial arterial embolisation. J Bone Joint Surg Br. 2002;84(6):873-7. http://dx.doi.org/10.1302/0301620X.84B6.0840873. PMid:12211682.

16. Pazionis TJC, Papanastassiou ID, Maybody M, HealeyJH. Embolization of hypervascular bone metastases reduces intraoperative blood loss: a case-control study. Clin Orthop Relat Res. 2014;472(10):3179-87. http://dx.doi.org/10.1007/s11999-014-3734-3. PMid:24964883.

17. Barton PP, Waneck RE, Karnel FJ, Ritschl P, Kramer J, Lechner GL. Embolization of bone metastases. J Vasc Interv Radiol. 1996;7(1):81-8. http://dx.doi.org/10.1016/S1051-0443(96)70738-8. PMid:8773979.

Correspondence Felipe Soares Ribeiro Hospital Porto Dias Av. Almirante Barroso, 1454 - Bairro Marco CEP: 66093-020 - Belém (PA), Brasil Tel.: +55 (91) $98898-3883$ / +55 (91) $98408-2286$ E-mail: feliperibeiro000@hotmail.com; feliperibeiro000@usp.br

Author information

FSR - Doctoral candidate, Universidade de São Paulo, Departamento de Cirurgia, Programa de Anestesiologia, Ciências Cirúrgicas e Medicina Perioperatória; Serviço de Cirurgia Vascular e Endovascular coordinator, Hospital Porto Dias; Board Certified in Cirurgia Vascular, Cirurgia Endovascular e Ecografia Vascular com Doppler, Sociedade Brasileira de Angiologia e de Cirurgia Vascular (SBACV), Associação Médica Brasileira (AMB), Colégio Brasileiro de Radiologia (CBR). FBCF - Board certified in Ortopedia e Oncologia Ortopédica; Full Member, Sociedade Brasileira de Ortopedia e Traumatologia (SBOT); Full Member, Associação Brasileira de Oncologia Ortopédica (SBOO); Chief of Serviço de Oncologia Ortopédica, Hospital Porto Dias. HBRN - Master's Candidate in Cirurgia e Pesquisa Experimental, Universidade do Estado do Pará (UEPA); Board Certified, Cirurgia Vascular, Sociedade Brasileira de Angiologia e de Cirurgia Vascular (SBACV), Associação Médica Brasileira (AMB). SAHJ - Board certified in Cirurgia Vascular, Sociedade Brasileira de Angiologia e de Cirurgia Vascular (SBACV); Adjunct Professor of Cirurgia Vascular, Universidade Federal do Pará. JVFS, AVBSD and TMMFS - Medical Students, Faculdade Metropolitana da Amazônia (UNIFAMAZ).

Author contributions Conception and design: FSR, SAHJ, FBCF. Analysis and interpretation: FSR, JVFS, TMMFS, AVBSD Data collection: FSR, HRBN, JVFS, TMMFS, AVBSD Writing the article: FSR, JVFS, TMMFS, AVBSD Critical revision of the article: FSR, HRBN Final approval of the article: FSR, HRBN Statistical analysis: N/A. Overall responsibility: FSR

*All authors have read and approved of the final version of the article submitted to I Vasc Bras. 